\title{
200 let vědecké paleobotaniky
}

\author{
Jiří Kvaček
}

Národní muzeum, Václavské náměstí 68, 11000 Praha 1

Kvaček J., 2020: 200 let vědecké paleobotaniky. - Journal of the National Museum (Prague), Natural History Series 189: 227-234.

Rok 2020 je pro obor zabývající se fosilními rostlinami - paleobotaniku, někdy zvanou fytopaleontologie, rokem jubilejním. Právě letos uplyne 200 let od vydání prvního dílu knihy Kašpara Sternberga Flora der Vorwelt, která se stala v paleobotanice významným mezníkem celosvětového významu. Neblahá situace způsobená světovou pandemií čínské chřipky zapříčinila, že oslavy, které Národní muzeum a světová organizace paleobotaniků (International Organisation of Palaeobotany) společně připravovaly, nemohly proběhnout $\mathrm{v}$ rámci chystané mezinárodní paleobotanické a palynologické konference v září tohoto roku. Připomenutí kulatého jubilea je tak hlavním motivem tohoto krátkého článku.

Kašpar Maria hrabě Sternberg je vedle Adolfa Brongniarta a Fridricha A. Schlotheima považován za jednoho ze zakladatelů světové vědecké paleobotaniky (Andrews 1980, Bowden a kol. 2005). Sternberg mezi nimi vyniká tím, že jeho dílo Versuch einer geognostisch-botanischen Darstellung der Flora der Vorwelt, zkracované obvykle jako Flora der Vorwelt, je celosvětově uznáváno jako první vědecké dílo oboru, proto je datum vydání jeho prvního dílu 31. 12. 1820 kodifikováno jako počátek tzv. „starting point“ paleobtanického názvosloví.

Jedním z důvodů, proč je dílo uznáváno až do současnosti, je skutečnost, že Kašpar Sternberg jako botanik měl na fosilní rostliny významně odlišný pohled než většina jeho současníků. Považoval je za skutečné, kdysi žijící rostliny, ne za hříčky neživé přírody - tzv. Petrefacta (např. Schlotheim 1820). Sternberg ve svém popisu flóry prasvěta použil pro klasifikaci rostlin

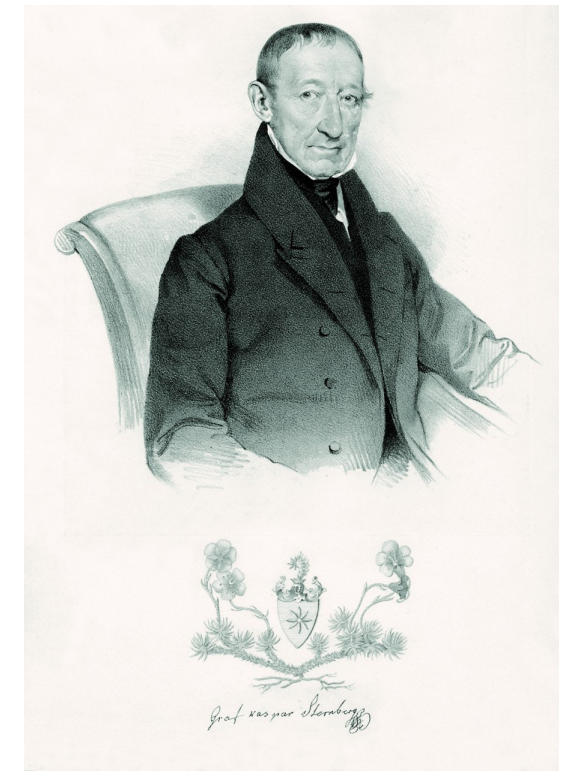

Obr. 1. Kašpar Maria hrabě Sternberg (A. Clarot 1838). Litografie doplněná perokresbou lomikamene a Sternbergovým vlastnoručním podpisem, kterou věnoval některému ze svých přátel z Řezenské botanické společnosti. Archiv Regensburgische Botanische Gesellschaft. 


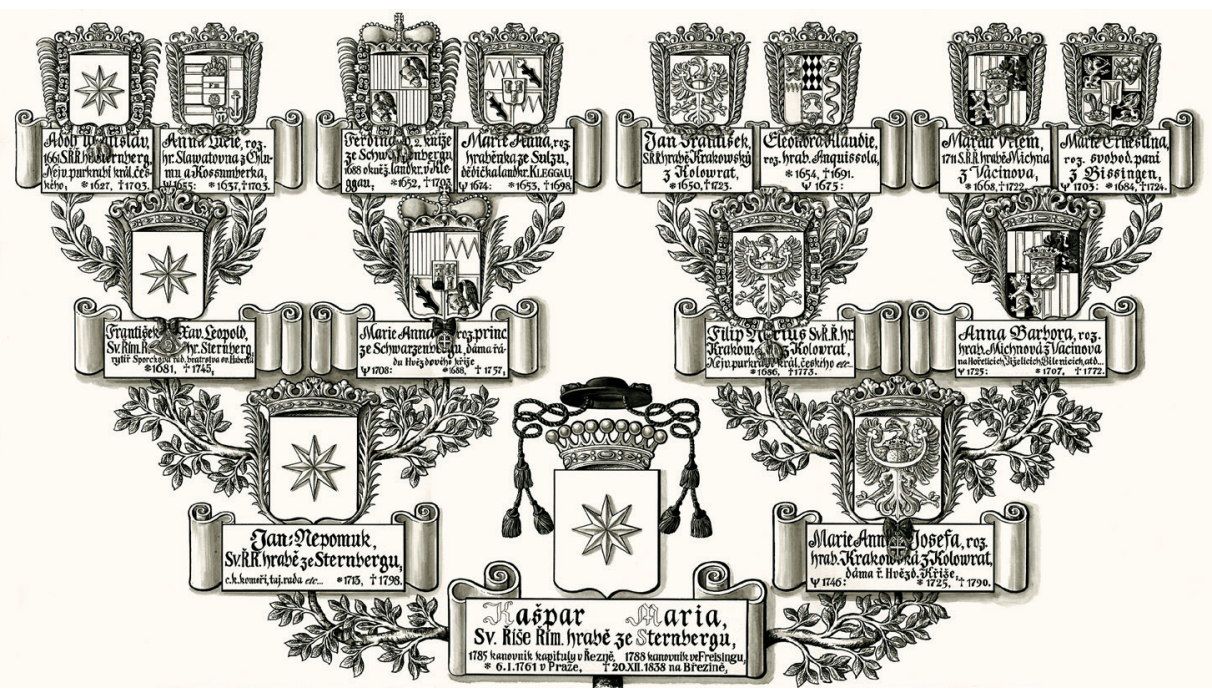

Obr. 2. Genealogický vývod K. M. hraběte Sternberga. Národní muzeum, autor: P. Tybitancl, 1998.

obdobný systém taxonomických hierarchií, který byl od dob Karla Linného užíván u rostlin žijících (Schimper 1869). Každý taxon od úrovně rodu dolů doplnil latinskou diagnózou a obrázkem nebo odkazem na obrázek již publikovaný někým jiným. Použil princip, který je ve vědecké paleobotanice používán do dnešní doby.

Kašpar Maria hrabě Sternberg se narodil 6. ledna 1761 v Praze, jako třetí syn Jana Nepomuka hraběte Sternberga a Anny hraběnky Sternbergové, rozené Kolowrat Krakowské. Otec byl důstojníkem v rakouské armádě. Nadání $\mathrm{k}$ př́rodním vědám zdědil mladý Kašpar jistě po své matce, která byla velice vzdělanou ženou (Kvaček \& Pátová 1998). Mládí prožil mladý Kašpar na zámku v Radnicích a v Oseku u Rokycan, později studoval v Praze a v Římě, kde se připravoval na církevní kariéru. V roce 1785 byl jmenován kanovníkem v Řezně, kde mu byla svěřena péče o lesy. $\mathrm{V}$ práci mu jistě pomohl jeho od dětství projevovaný zájem o př́rodu. $\mathrm{V}$ jeho novém působišti jej stále více přitahovala botanika, proto se v roce 1795 rozhodl vstoupit do Botanické společnosti v Řezně ${ }^{1}$. V Řezně, které bylo v té době živým městem, centrem kultury i vzdělanosti, se Sternbergovi neočekávaně naskytla i politická kariéra. V roce 1802 bylo z Mohuče do Řezna přeneseno sídlo Svaté říše Římské, Sternberg v něm hrál důležitou roli, byl jmenován víceprezidentem zastupoval dlouhodobě nemocného prezidenta Karla Anselma Thurn-Taxise, cestoval, vedl politická jednání. V té době se zdálo, že Kašpar Sternberg v Řeznu zůstane natrvalo. V roce 1804 si na okraji Řezna postavil vilu s botanickou zahradou, účastnil se jak politického, tak vědeckého života města. $V$ turbulentní době napoleonských válek se ale politická situace v Evropě začala měnit. Se změnou se dostavovalo Sternbergovo znechucení z politiky, které vyvrcholilo po jeho neúspěšné kandidatuře na vysoký politický post ve státním aparátu Svaté říše Římské. V té době se Kašpar Sternberg rozhodl plně se věnovat přírodním vědám. Začal zpracovávat monografii o alpínských rostlinách - lomikamenech, která vyšla v roce 1810 (později vyšly ještě její dva suplementy Sternberg 1822, 1831). Vedle botaniky jej již tehdy upoutaly fosilní rostliny. Ve svém prvním paleobotanickém článku (Sternberg 1804), který vznikl jako reakce na článek barona Schlotheima (Schlotheim 1804), upozorňuje na to, že fosilní rostliny, které byly nalezeny v okolí Manebachu v Německu, tzn. v oblasti mírného pásma, musely pủvodně rủst v podnebí mnohem teplejším. Zároveň poukazuje na to, že jejich jemné složené listy se v sedimentu

1 Botanická společnost v Řezně (založena 1790) je nejdéle existující profesní spolek na světě. 
zachovaly poměrně kompletní, proto nemohly být do mírného pásma zaneseny např. mořskými proudy, nýbrž že se musely uložit v místě, kde takové teplé podnebí panovalo.

Ve svém deníku si Sternberg v roce 1805 poznamenal: "U Thouina (v Pařiži) jsem se seznámil s Faujasem de St. Fond, který mě zavedl do vlastní sbírky, aby mi ukázal rostlinné otisky z Anglie. Při té prríležitosti jsem si připomněl podobné otisky ze sbírky mého bratra z jeho uhelných dolü" (Palacký 1868).

Smrt bratra Jáchyma, který byl vlastníkem Sternbergského panství a zničení vlastního domu a zahrady po Napoleonově invazi do Řezna znamenaly velký zlom ve Sternbergově životě. $\mathrm{V}$ roce 1810 se Kašpar Sternberg rozhodl vrátit do Čech. Usadil se v Březině, kde dokončil po bratrovi rozestavěný zámek. Kolem něj vybudoval velkou botanickou zahradu. Hlavně však začal zděděné panství zvelebovat. Zajímal se o již běžící těžbu surovin, především černého uhlí a zpracování železné rudy. $\mathrm{V}$ bratrově sbírce a ve svých dolech se Kašpar Sternberg setkal znovu s fosilními rostlinami, tentokrát je však mohl mnohem detailněji studovat. Fosilní rostliny Sternberga zcela zaujaly. Společně s místními př́rodovědci Janem D. Preyslerem a Janem T. Lindackerem, kteří u něj pracovali, jako důlní inženýři sbírali fosílie na radnických dolech. Sbírku obohatil i o sběry z jiných částí Čech, z okolí Sokolova, Doupovských hor, Bíliny, Nového Bydžova, Kounic a blízkého zahraničí, např. z Walbrzychu. Sternberg často cestoval a navštěvoval sbírky i terény svých přátel, hlavně v Německu a v Prusku. Mezi jeho nejbližší kolegy patřili: Georg hr. Münster z Bayreuthu, Ernst Fridrich baron Scholtheim z Gothy, Jacob Nöggerath z Bonnu, Johann Wolfgang Goethe $\mathrm{z}$ Výmaru. Fosílie mu kolegové z ciziny zasílali poštou. Dopisoval si napřs s Williamem Bucklandem z Oxfordu, se Svenem Nilssonem a Carlem A. Agardhem z Lundu. Sternberg tak vytvořil sbírku,

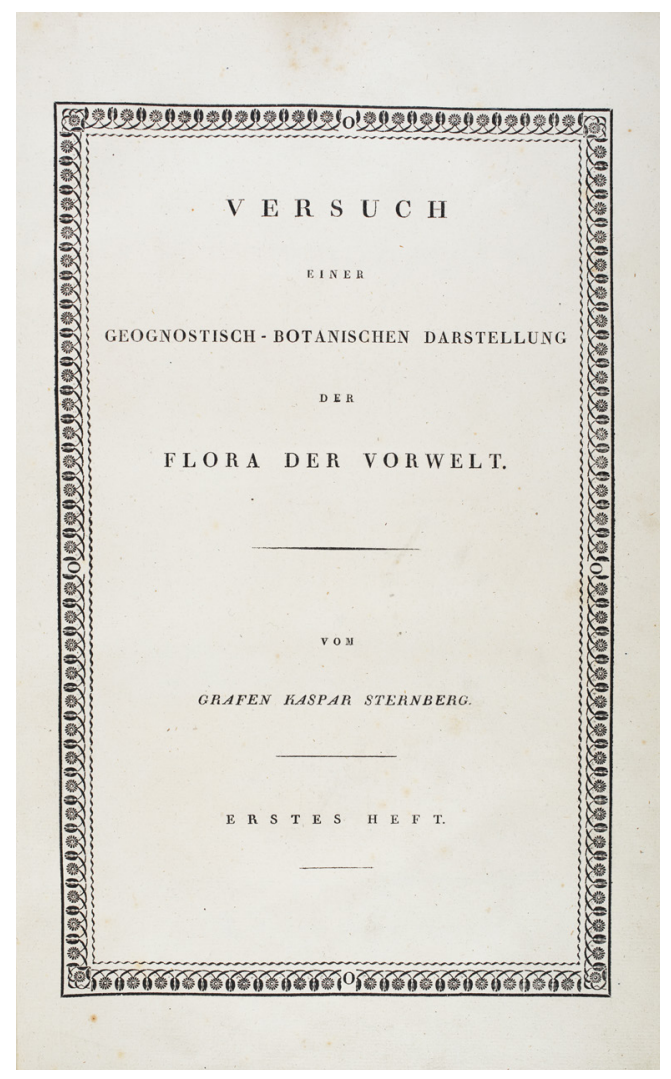

Obr. 3. Titulní strana prvního dílu knihy K. M. Sternberga z roku 1820 Versuch einer geognostisch-botanischen Darstellung der Flora der Vorwelt. Knihovna Národního muzea.

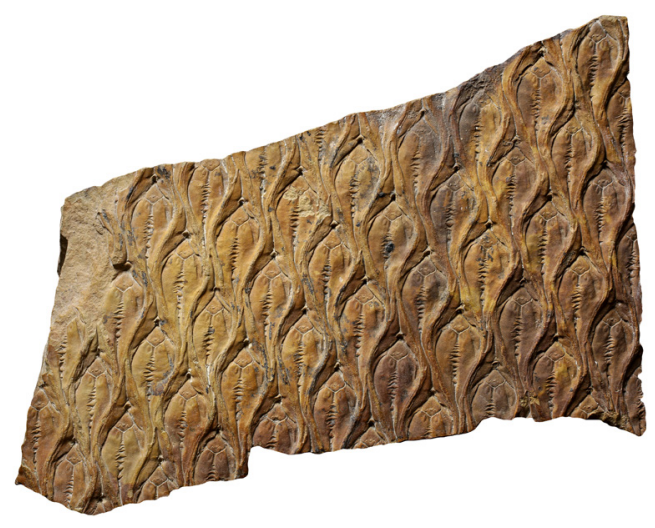

Obr. 4. Lepidodendron aculeatum Sternberg 1820, holotyp, otisk kůry stromovité plavuně, karbon, Radnice, No. E 4671, paleontologická sbírka Národního muzea. 


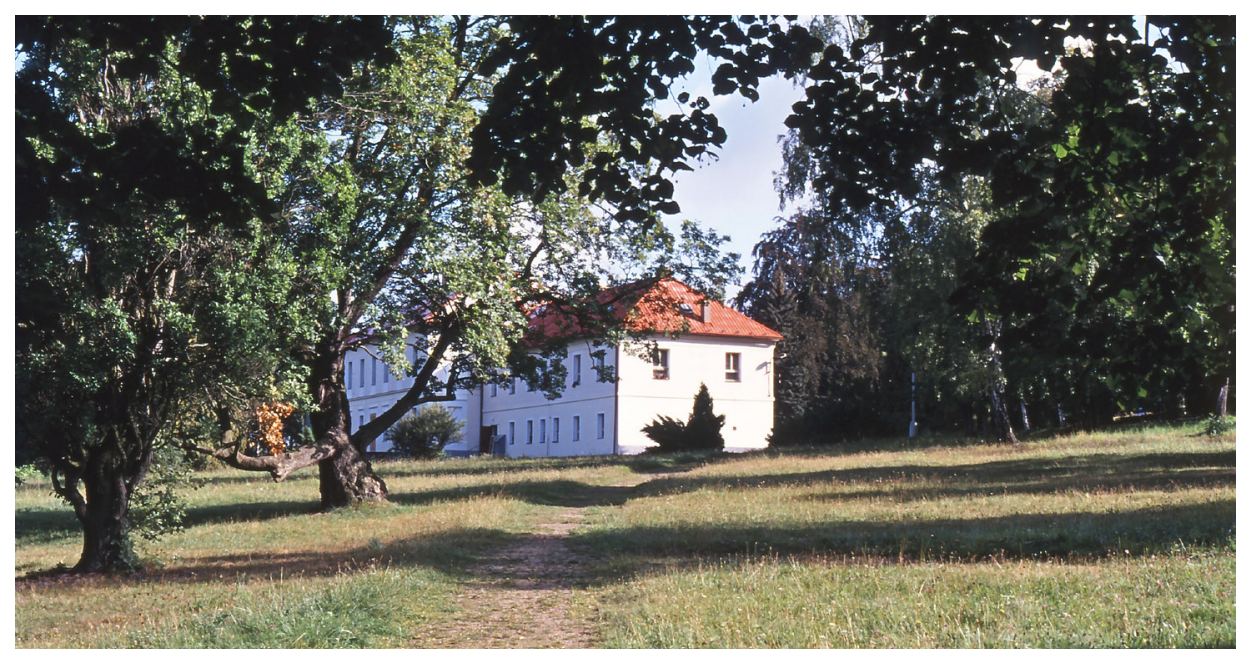

Obr. 5. Zámek Březina se zahradou. Foto: J. Kvaček.

o které Alexander Humboldt, který když ji navštívil, prohlásil, že „žádná sbírka na světě nad množstvím, krásou a vzácností exemplářu a vědeckou důležitostí nevyniká" (Nebeský 1868²).

Sbírka se stala Sternbergovi zdrojem velkolepě koncipovaného díla o fosilních rostlinách Flora der Vorwelt, které začalo vycházet počínaje rokem 1820. Monografie ve dvou svazcích se skládá z celkem osmi dílů (Sternberg 1820-1825, 1833-1838). Kromě detailních popisů fosilních rostlin Sternberg doprovodil dílo i kvalitními ilustracemi. Nelitoval peněz, aby zaplatil co nejlepší malíre a rytce, kteří doplnili dílo ilustracemi na 136 ručně kolorovaných tabulích. Malíre si Sternberg vybíral uváženě (Cleal a kol. 2005). Někteří jako J. D. Preysler nebo August C. J. Corda byli jeho vlastní spolupracovníci, mezi dalšími jmenujme alespoň ty nejčastěji zastoupené: E. Anton Auinger, Jurgend Schmelda, Franz Both. Mědirytecké práce Sternberg svěřil osvědčenému rytci botanických děl Jacobu Sturmovi z Norimberka. Jen část tabulí ke Cordově článku (55bis, 61-68) byla tištěna v Praze jako litografie (Kvaček \& Kvaček 1992).

Kašpar Sternberg a jeho spolupracovníci Karel Bořivoj Presl a August Karl J. Corda, kteří mu pomáhali s přípravou posledního dílu, popsali ve společném díle 623 nových fosilních rostlin, 83 rodů a 540 druhů a poddruhů (Kvaček \& Straková 1997). Další fosilní rostliny popsal Sternberg v drobnějších, mnohdy pozapomenutých článcích, a tak konečný počet jím popsaných taxonů bude upřesněn v rámci nově připravované revize katalogu (Kvaček a kol. v přípravě). Každý taxon je reprezentován alespoň jedním kusem - holotypem, obvykle však více kusy - syntypy. Jen část popisovaných kusů však pochází ze Sternbergovy sbírky ${ }^{3}$ uložené v Národním muzeu. Sternbergovy kusy se od ostatních kusů sbírky poznají podle drobných rámovaných čísel, které pro celou sbírku pořídil Franz.X. Zippe, jenž byl prvním kustodem sbírky v letech 1824-1849. Další typové exempláře ke Sternbergovým druhům jsou uloženy v mnoha evropských přírodovědeckých muzeích: Bayerische Staatssammlung für Paläontologie und Geologie, München; Geowissenschaftliches Museum der Universität Göttingen; Great North Museum: Hancock, Newcastle upon Tyne; Hunterian Museum - University of Glasgow; Natural History Museum, London; Museum für Naturkunde, Berlin; Muséum national d'Histoire naturelle, Paris; Naturhistoriska riksmuseet, Stockholm; Naturkundemuseum Stuttgart;

2 Sbírka podle Palackého v roce 1842 čítala 1398 kusů (Palacký 1842).

3 Někdy se také sbírka nazývala Sternberg-Lindackerova. Sternberg s Lindackerem se domluvili o spojení svých sbírek do nedělitelného celku (Jíra 2018). Název sbírka Sternberg-Lindacekr nesou i staré sbírkové skříně, které pravděpodobně sloužily k původnímu uložení sbírky. V současné době jsou v inventáři Náprstkova muzea. 


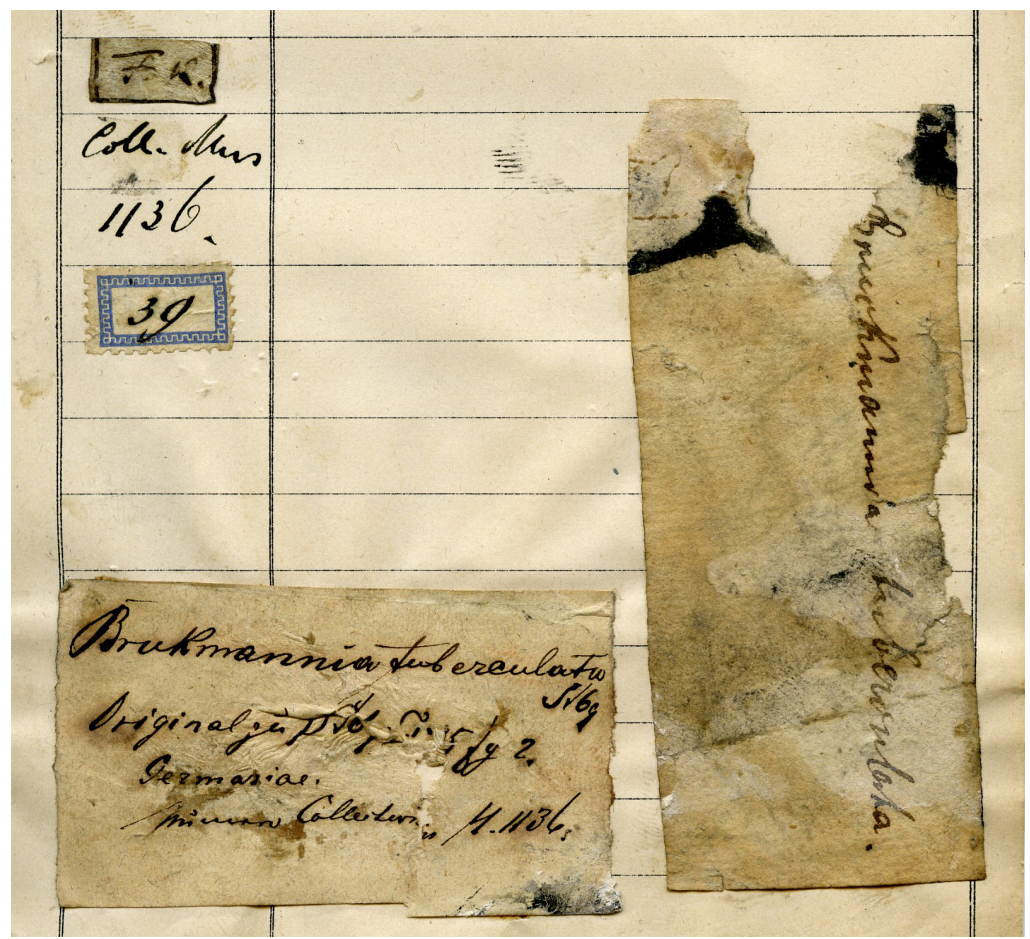

Obr. 6. Originální etikety k níže vyobrazenému kusu ze sbírky Kašpara M. hraběte Sternberga. Vlevo nahoře poškozené číslo Sternbergovy sbírky 1136; vpravo poškozená etiketa se Sternbergovým rukopisem.

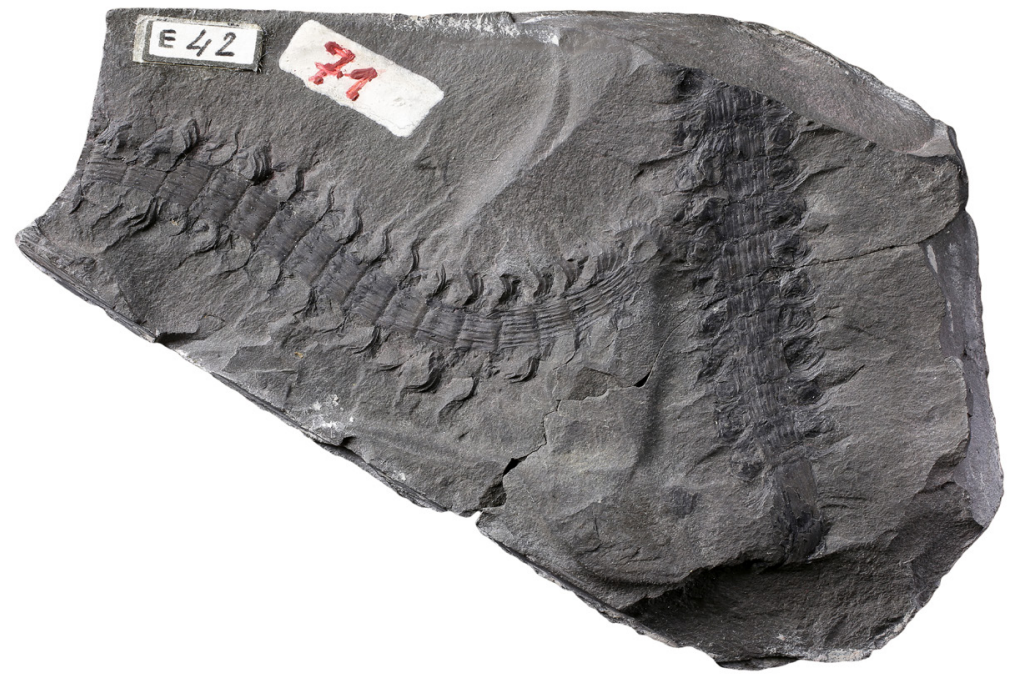

Obr. 7. Otisk šištice prvohorní přesličky Clamostachys tuberculata, kterou věnoval K. M. Sternbergovi J. W. Goethe. Paleontologická sbírka Národního muzea, č. NM-E 42. 


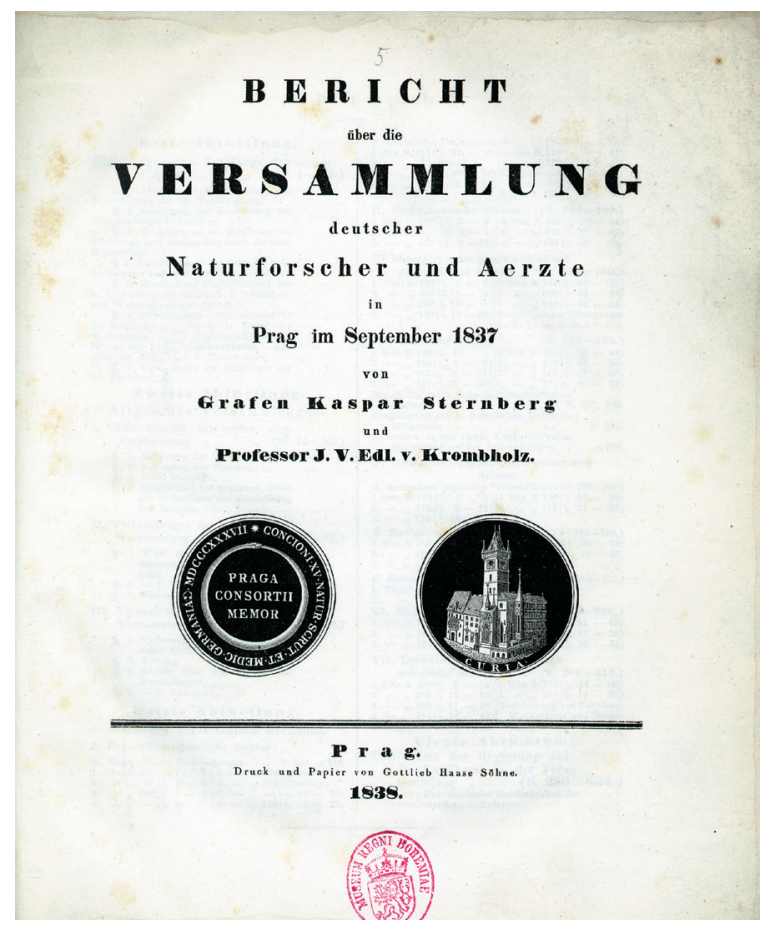

Obr. 8. Titulní list knihy věnované 15 . kongresu německých lékařů a prírodovědců, který se konal 18.-26. zárí 1837 v Praze.
Oxford University Museum of Natural History.

Kašpar Sternberg byl však nejen vědcem, má i zásluhy vlastenecké, je považován za vůdčí zakladatelskou osobnost Národního muzea. $\mathrm{V}$ roce 1814 Sternberg navštívil muzeum Joanneum ve Štýrském Hradci. Asi si chtěl upřesnit představu o založení českého národního muzea. Společně s dalšími českými aristokraty se mu skutečně podařilo myšlenku muzea prosadit a publikovat formou dopisu adresovaného vlasteneckým přátelům věd $\mathrm{v}$ roce 1818. Společnost Národního muzea jako jeho správní orgán byla založena 23. prosince v roce 1822 a hrabě Sternberg byl zvolen jejím prezidentem. Do vínku nově vzniklého muzea Kašpar Sternberg věnoval celou svou sbírku přírodnin, včetně fosilních rostlin, a rozsáhlou vědeckou knihovnu.

Kašpar Sternberg byl neúnavný organizátor i $\mathrm{v}$ dalších oborech, především $\mathrm{v}$ průmys-

lu a zpracování nerostných surovin, ale i v zemědělství. Jeho další aktivity detailně mapuje J. Majer ve své monografii Kašpa Šternberk (Majer 1997). Na konci života se mu splnil i další jeho plán - uspořádat v Praze mezinárodní vědeckou konferenci. Po dlouhých př́ípravách se mu nakonec podařilo dohodnout s německými vědci, zastoupenými Lorenzem Okenem, na zorganizování 15. kongresu německých lékařủ a př́rodovědců v Praze v roce 1837.

Kašpar Sternberg byl aktivní celý svůj život a zůstal až do jeho konce. Ještě v posledním roce svého života se zúčastnil zasedání Společnosti Národního muzea a v prosinci uspořádal tradiční hon. Na něm jej stihla mozková mrtvice, které podlehl 20. prosince 1838 ve věku 76 let.

Je velkou škodou, že zásluhy tohoto českého šlechtice nebyly v minulosti nějakým zvlášt' výrazným způsobem zviditelněny. V Praze se po něm nejmenuje ani ulice. Možná za to mohl jeho aristokratický původ, který se nehodil ani v době obrození, ani za první republiky, ani v době komunismu. Přitom jde o zakladatele národní instituce, zakladatele vědního oboru, štědrého mecenáše a vynikajícího vědce. Proto je dobré na závěr zopakovat, že Kašpar Sternberg je jedením z největších českých přírodovědců 19. století, který výrazným způsobem předběhl svými myšlenkami dobu a přispěl k světovému věhlasu české přírodovědy.

\section{Literatura}

Andrews, H.N., 1980: Fossil Hunters. - London: Cornell University Press, 421 pp.

Bowden, A.J., Burek, C.V., Wilding R. (eds), 2005: History of palaeobotany: Selected essays. Geological Society, London, Special Publications 241: 312 pp. 
Cleal C.J., Lazarus M., Townsend A., 2005: Illustrations and illustrators during the ,Golden Age' of palaeobotany: 1800-1840. - In: Bowden, A.J., Burek, C.V., Wilding, R. (eds): History of palaeobotany: selected essays. Geological Society London Special Publications 241, 1: 41-61.

Jíra J., 2018: Osobnost Jana Tadeáše Lindackera. - Česká astronomická společnost, Západočeská pobočka, https://www.astro.zcu.cz/cs/clanky/clanek/347/ [Accessed on 5 November 2020]

Kvaček J., Pátová R. (eds), 1998: Kašpar M. hrabě Sternberg, př́rodovědec a zakladatel Národního muzea. - Praha: Národní muzeum, 104 pp.

Kvaček J., Straková M., 1997: Catalogue of fossil plants described in works of Kašpar M. Sternberg. - Praha: Národní muzeum, 201 pp.

Kvaček Z., Kvaček J., 1992: Šternberkovo dílo Flora der Vorwelt, jeho význam a stav dokladové sbírky. - Časopis Národního muzea v Praze, Řada přírodovědná 158, 1-4: 41-42.

Majer J., 1997: Kašpar M. Šternberk. - Praha: Academia, 227 pp.

Nebeský V., 1868: Dějiny muzea Království českého. - Praha: Muzeum Království českého, $208 \mathrm{pp}$.

Palacký F., 1842: Das vaterländische Museum in Böhmen im Jahre 1842. - Praha: Museum. pp. 74.

Palacký F., 1868: Das Leben des Grafen Kaspar Sternberg. - Praha: Fr. Tempsky, 242 pp.

Schimper W.P., 1869: Traité de paléontologie végétale. - Paris: J. B. bailliere et fils, 738 pp.

SchlotheimE.F., 1804: Flora der Vorweltoder Beschreibungen merkwürdiger Kräuterabdrücke und Pflanzenversteinerungen. - Gotha: Becker'schen Buchhandlung, 68 pp.

Schlotheim E.F., 1820: Die Petrefactenkunde auf ihrem jetztigen Standtpunkte. - Gotha: Becker'schen Buchhandlung, $435 \mathrm{pp}$.

Sternberg K.M., 1804: Notice sur les analogues des plantes fossiles. - Annales du Muséum national d histoire naturelle, 5: 462-470.

Sternberg K.M., 1810: Revisio Saxifragarum Iconibus lllustrata. - Regensburg: H.F.A. Augustin, $62 \mathrm{pp}$.

Sternberg K.M., 1822: Revisio Saxifragarum Iconibus Illustratae. Supplementarum. Regensburg: C.E. Brencks Witwe, 16 pp.

Sternberg K.M., 1831: Revisio Saxifragarum Iconibus Illustrata. Supplementum secundum. Prague: G. Calve, 104 pp.

Sternberg K.M., 1820-1838: Versuch einer geognostischbotanischen Darstellung der Flora der Vorwelt. - Vol. I, 1 (1820), 24 pp., pls. 1-13, Leipzig: F. Fleischer; vol. I, 2 (1821), 33 pp., pls. 14-26, Leipzig: F. Fleischer; vol. I, 3 (1823), 39 pp., pls. 27-39, Regensburg: Ernst Brenck's Wittwe; vol. I, 4 (1825), 48 pp. tent. I-XLII, pls. 40-59, Regensburg: Ernst Brenck's Wittwe; vol. I, 5/6, (1833), 80 pp., pls. 1-26, Prague: Johann Spurny; vol. II, 7/8: 81-220, pls. 27-68 A, B, Prague: Gotlieb Haase Söhne. 


\section{Summary}

\section{0 years of scientific palaeobotany}

Jiří Kvaček

In the year 2020, we celebrate 200 years of scientific palaeobotany, and 200 years since the issue of the first part of the Sternberg Flora der Vorwelt. Kašpar Sternberg (1761-1838) is considered to be the principal founder of scientific palaeobotany besides Adolf Brongniart and Fridricha A. Schlotheim. His seminal work Versuch einer geognostisch-botanischen Darstellung der Flora der Vorwelt (abbreviated usually as Flora der Vorwelt) is well known through the palaeobotanical community as the starting point of palaeobotanical nomenclature. Sternberg, being equipped with a botanical background, took a significantly different approach to fossil plants than the majority of his contemporaries. He used the Linnaean system of taxa in palaeobotany, ordered in natural hierarchies. Each taxon below the level of genus he designated with a distinct Latin diagnosis and an illustration or reference to earlier published fossils. In that way, each taxon was associated with its type. In his approach, he did not consider fossils as „Petrefacta“ but as fossils of real plants, which lived once in nature.

In the Czech Republic, we also celebrate Kašpar M. Sternberg as a founder of the National Museum (established in 1818), an organizer of various industrial activities, an enthusiastic supporter of national enlightenment, and a generous patron of Czech science and culture. 